\title{
Sugarcane bagasse as exclusive roughage for dairy cows in smallholder livestock system
}

\author{
Gleidiana Amélia Pontes de Almeida, ${ }^{1, *}$ Marcelo de Andrade Ferreira', Janaina de Lima Silva ${ }^{2}$, \\ Juana Catarina Cariri Chagas ${ }^{1}{ }^{*}$, Antônia Sherlânea Chaves Véras ${ }^{1}$, \\ Leonardo José Assis de Barros ${ }^{1}$, and Gledson Luiz Pontes de Almeida ${ }^{3}$
}

\footnotetext{
* Corresponding Authors:

Gleidiana Amélia Pontes de Almeida

Tel: +55-081-33206569, Fax: +55-081-33206560,

E-mail: ameliazootecnia@gmail.com

Juana Catarina Cariri Chagas

Tel: +55-081-33206569, Fax: +55-081-33206560,

E-mail: juanachagas@gmail.com

${ }^{1}$ Department of Animal Science, Federal Rural University of Pernambuco, Recife, PE, CEP 52171 900, Brazil

${ }^{2}$ Multidisciplinary Barra Center, Federal University of Western Bahia, Barra, BA, CEP: 47100-000, Brazil

${ }^{3}$ Department of Agricultural Engineering, Federal Rural University of Pernambuco, Recife, PE, CEP: 52171900 , Brazil
}

\section{ORCID}

Gleidiana Amélia Pontes de Almeida https://orcid.org/0000-0001-8315-7465 Marcelo de Andrade Ferreira

https://orcid.org/0000-0002-9155-4388 Janaina de Lima Silva

https://orcid.org/0000-0001-8067-7588 Juana Catarina Cariri Chagas https://orcid.org/0000-0001-6982-425X Antônia Sherlânea Chaves Véras

https://orcid.org/0000-0002-7673-0654 Leonardo José Assis de Barros

https://orcid.org/0000-0002-0339-4696

Gledson Luiz Pontes de Almeida

https://orcid.org/0000-0002-5813-4517

Submitted Mar 17, 2017; Revised Jun 25, 2017; Accepted Oct 12, 2017
Objective: The study aimed to evaluate sugarcane bagasse as roughage in lactating cow on feed intake, digestibility, ingestive behavior, milk production and composition, and microbial protein synthesis.

Methods: Ten Girolando cows at initial body weight of $450 \pm 25.6 \mathrm{~kg}$ and at $143.7 \pm 30.7$ days in milk were assigned in two $5 \times 5$ Latin square designs. Five 21 -day experimental periods were adopted ( $1^{\circ}$ to 14 -day: diets adaptation period; $15^{\circ}$ to 21 -day: data collection and sampling period). The diets consisted of four different levels of sugarcane bagasse (45\%,50\%, 55\%, and 60\%) and a control diet, commonly adopted in the region, based on spineless cactus (25\% sugarcane bagasse), formulated to meet $12 \mathrm{~kg} / \mathrm{d}$ milk yield.

Results: The dry matter $(\mathrm{DM})$, organic matter $(\mathrm{OM})$, and total digestible nutrients intakes and DM and OM digestibilities observed for $45 \%$ and $50 \%$ bagasse inclusion were similar to control diet, while that $55 \%$ and $60 \%$ bagasse inclusion were lower. Cows fed control diet, and bagasse diets of $45 \%$, and $50 \%$ levels had the nutritional requirements attended, that guaranteed $12 \mathrm{~kg} / \mathrm{d}$ of milk yield. The crude protein intake and digestibility of cows fed $45 \%$, $50 \%$, and $55 \%$ of bagasse inclusion were similar to control diet. The neutral detergent fiber (NDF) intake and digestibility differ for all bagasse diets related to control diet, while the nonfiber carbohydrates intake and digestibility for cows fed $45 \%$ of bagasse were similar for control diet. The intakes and digestibilities of nutrients decreased linearly in function of bagasse inclusion; NDF and indigestible NDF intakes did not vary. The ruminating time, feeding and rumination efficiency, microbial protein synthesis and milk yield decreased linearly with sugarcane bagasse inclusion.

Conclusion: Sugarcane bagasse decreases milk production; however, its inclusion level in between $45 \%$ to $50 \%$ associated to concentrate could replace diets based on spineless cactus for crossbred dairy cow's producing $12 \mathrm{~kg} / \mathrm{d}$ of milk.

Keywords: Drought Season; Livelihoods; Alternative Roughage; Crossbred Dairy Cattle; Microbial Protein

\section{INTRODUCTION}

The dairy cattle production system in the most of semiarid region in Brazil is characterized by smallholder livestock system, which is responsible for $80 \%$ of world consumption food and was considered by UN (United Nations) as production system able to collaborate for global hunger eradication and achieve the sustainable feeding security [1]. Climate change has led to frequent and prolonged periods of drought in arid and semiarid regions, as a result of irregular rainfall and high temperatures. These extreme weather factors will be amplified in the future because of global warming, negatively affecting the availability of food throughout the seasons of the year [2]. The consequence of drought is a fall in crop production and 
pasture growth, leading to weight loss and increased deaths of animals [3].

The spineless cactus, which is considered an essential roughage ingredient in ruminant's diets, in particular for dairy cattle in arid and semiarid region [4], became unfeasible in the last years since the plague (Dactylopius opuntias) has expanded in spineless cactus field. The insect-plague found favorable conditions in the dry season to grow, affecting and compromising millions of spineless cactus hectares, which lead the producers to find an alternative roughage for cattle.

Brazil is the largest sugarcane producer in the world, with around 719.1 million tons produced annually [5]. One of the main sugarcane processing agroindustrial waste is sugarcane bagasse, resulting from the crushing of sugarcane during extraction or direct transformation of alcohol [6]. It is conceded a low-quality roughage presenting $40 \%$ of ingestible fiber and low crude protein (CP) content, however, one advantage of sugarcane bagasse is its availability during times of fodder shortage and its low cost compared with other conventional sources of roughage [7]. In this scenario, the sugarcane bagasse became the only viable alternative, in short, and medium-term, as roughage for dairy cattle diets to replacing the spineless cactus.

Most of the work testing sugarcane bagasse has been performed with beef cattle, aiming to maximize their performance. Authors reported that sugarcane bagasse could be used as an exclusive source of roughage for beef cattle [8]. Therefore, the increase in volume of sugarcane bagasse produced in recent years represents a potential source of animal nutrition. There is now interest in investigating the optimal level of sugarcane bagasse for dairy cows since their nutritional requirements differ from beef cattle and there is no research using sugarcane bagasse as exclusive roughage for this category of animals.

Thus, the study aimed evaluated sugarcane bagasse use as exclusive roughage in lactating cow on feed intake, digestibility, ingestive behavior, milk production and composition, and microbial protein synthesis.

\section{MATERIALS AND METHODS}

\section{Animal care}

All procedures were conducted in accordance with the guidelines set out by the Brazilian College of Animal Experimentation in the Code of Practice for the Care and Use of Animal for Experimental Purposes and were reviewed and approved by the Ethics Committee on Use of Animal for Research (CEUA) of the Federal Rural University of Pernambuco, under license number 033/2014.

The experiment was conducted at Capoeiras City, Pernambuco, Brazil. The average rainfall in the region is $588 \mathrm{~mm} / \mathrm{yr}$ with an average annual temperature of $22.1^{\circ} \mathrm{C}$. According to the climatic classification of [9] the climate of the region is characterized as Bsh, semiarid.

\section{Animals and diests}

Ten Girolando cows (3/4 Holstein-Gyr) with an average initial weight of $450 \pm 25.6 \mathrm{~kg}$ and at $143.7 \pm 30.7$ days in milk were assigned into two $5 \times 5$ Latin square designs defined according to their milk yield in the adaptation period ( 10 and $14 \mathrm{~kg} / \mathrm{d}$, respectively). The cows were housed in individual $16 \mathrm{~m}^{2}$ pens (semi-covered), with individuals feeders and drinkers. The experimental lasted 105 days in total, divided into five 21-day experimental periods, which was periodized in $1^{\circ}$ to $14^{\circ}$ day (diets adaptation periods), $15^{\circ}$ to $21^{\circ}$ day (data and sampling collection of intake, leftover, and milk yield), $17^{\circ}$ day (urine and blood collection), $17^{\circ}$ to $21^{\circ}$ day (digestibility assay [feces collection]), $19^{\circ}$ to $21^{\circ}$ day (ingestive behavior observation), $20^{\circ}$ to $21^{\circ}$ day (milk collection). The ingredients of the diets are shown in Table 1 . The diets consisted of four different levels of sugarcane bagasse $(45 \%, 50 \%, 55 \%$, and $60 \%$ on a dry matter $[\mathrm{DM}]$ basis) and a control diet commonly adopted in the region for dairy cattle based on spineless cactus with $25 \%$ sugarcane bagasse incluison formulated to achievean average milk yield of $12 \mathrm{~kg} / \mathrm{d}$ (Table 2). The diets were formulated to be isonitrogenous, according to the requirements calculated by the [10], for $450-\mathrm{kg}$ cows initially producing $12 \mathrm{~kg}$ of milk per day and $4 \%$ fat milk.

\section{Experimental procedure}

The diets were provided to animal as TMR twice daily $(07 \mathrm{~h}$ $00 \mathrm{~min}$ and $16 \mathrm{~h} 00 \mathrm{~min}$ ) after the morning ( $04 \mathrm{~h} 00 \mathrm{~min}$ ) and afternoon ( $16 \mathrm{~h} 00 \mathrm{~min}$ ) milking sessions. The amount of feed supplied was corrected daily to generate $10 \%$ of orts in the fresh matter. Samples of the feed and orts were collected daily in each experimental period and stored at $-20^{\circ} \mathrm{C}$ in airtight plastic bags. The body weight of each cow was measured at the start and the end of each experimental period.

Feeding behavior (ruminating, feeding and idling) of all cows was evaluated starting on the fifth day of each period for two consecutive days (every $10 \mathrm{~min}$ for $24 \mathrm{~h}$ each day) accord-

Table 1. Chemical composition of ingredients used in the experimental diets ( $\mathrm{g} / \mathrm{kg}$ of dry matter)

\begin{tabular}{lcccc}
\hline Item & $\begin{array}{c}\text { Sugarcane } \\
\text { bagasse }\end{array}$ & $\begin{array}{c}\text { Spineless cactus } \\
\text { (cv. Miúda) }\end{array}$ & $\begin{array}{c}\text { Ground } \\
\text { corn }\end{array}$ & $\begin{array}{c}\text { Soybean } \\
\text { meal }\end{array}$ \\
\hline Dry matter & 412 & 143 & 886 & 894 \\
Organic matter & 956 & 904 & 989 & 935 \\
Crude protein & 18.2 & 22.6 & 97.4 & 485 \\
Ether extract & 11.3 & 17.2 & 37.6 & 13.2 \\
aNDF(n) & 775 & 205 & 119 & 151 \\
iNDF & 414 & 102 & 17.0 & 15.5 \\
Lignin & 73.4 & 46.2 & 12.2 & 30.0 \\
\hline
\end{tabular}

aNDF(n), neutral detergent fiber assayed with a heat stable amylase and corrected for ash and nitrogenous compounds; iNDF, indigestible neutral detergent fiber. 
Table 2. Proportion of ingredients and chemical composition of the experimental diets

\begin{tabular}{|c|c|c|c|c|c|}
\hline \multirow{2}{*}{ Item } & \multirow{2}{*}{ Control } & \multicolumn{4}{|c|}{ Sugarcane bagasse (\%) } \\
\hline & & 45 & 50 & 55 & 60 \\
\hline \multicolumn{6}{|l|}{ Ingredients (g/kg) } \\
\hline Sugarcane bagasse & 250 & 450 & 500 & 550 & 600 \\
\hline Spineless cactus (cv. Miúda) & 494 & 0 & 0 & 0 & 0 \\
\hline Groundcorn & 0 & 334 & 274 & 214 & 154 \\
\hline Soybeanmeal & 240 & 200 & 210 & 220 & 230 \\
\hline Urea/AS ${ }^{1)}$ & 1.00 & 1.00 & 1.00 & 1.00 & 1.00 \\
\hline Salt & 5.00 & 5.00 & 5.00 & 5.00 & 5.00 \\
\hline Mineral| $\left.\right|^{2)}$ & 10.0 & 10.0 & 10.0 & 10.0 & 10.0 \\
\hline \multicolumn{6}{|c|}{ Diet composition ( $\mathrm{g} / \mathrm{kg}$ of dry matter) } \\
\hline Dry matter & 389 & 661 & 638 & 614 & 590 \\
\hline Organic matter & 910 & 947 & 945 & 943 & 932 \\
\hline Crude protein & 137 & 141 & 141 & 141 & 142 \\
\hline Ether extract & 15.5 & 21.3 & 19.7 & 18.2 & 16.6 \\
\hline aNDF(n) & 296 & 378 & 408 & 439 & 469 \\
\hline iNDF & 159 & 196 & 216 & 236 & 256 \\
\hline Non-fiber carbohydrates & 423 & 361 & 327 & 294 & 261 \\
\hline
\end{tabular}

aNDF(n), neutral detergent fiber assayed with a heat stable amylase and corrected for ash and nitrogenous compounds; iNDF, indigestible neutral detergent fiber.

1) 9 parts of urea and 1 part of ammonium sulphate (AS).

${ }^{2)}$ Components: dicalcium phosphate; limestone; salt; sulfur flower; zinc sulfate; copper sulfate; manganese sulfate; potassium iodate; sodium selenite.

ing to the scan sampling method proposed by [11]. The feed and rumination efficiencies $(\mathrm{kg} / \mathrm{h})$ of $\mathrm{DM}$, and neutral detergent fiber (NDF), were calculated by dividing the intake of each of these nutrients by the total feeding or the rumination times.

\section{Chemical and statistical analyses}

Milk samples were collected from the tenth to the 19th day of each period, and conditioned in plastic bottles containing a preservative (Bronopol, D \& F Control Systems, Inc., New York, NY, USA) for analyses of protein, fat, lactose, total solid contents, and urea according to the methods of [12]. To measure the concentration of milk allantoin, a mixture of $8 \mathrm{~mL}$ milk and $4 \mathrm{~mL}$ of trichloroacetic acid $(25 \% \mathrm{w} / \mathrm{v})$ was centrifuged (Sorvall ST16R, Thermo Fisher Scientific Inc., Waltham, MA, USA) for 10 minutes at 2,000 rpm. Subsequently the samples were filtered through Whatman paper with a porosity of 40 to obtain a precipitate, which was stored in plastic micro tubes at $-18^{\circ} \mathrm{C}$ for further analysis. The milk yield values were corrected for $4.0 \%$ fat according to [10].

Blood samples were collected on the 15 th day, $4 \mathrm{~h}$ after feeding, by coccygeal vein puncture, in two tubes: one containing anticoagulant (ethylenediaminetetraacetic acid) and another containing sodium fluoride. After collection, the blood samples were immediately centrifuged at $2,700 \times \mathrm{g}$ for $20 \mathrm{~min}$. The plasma samples were frozen at $-18^{\circ} \mathrm{C}$ for later analysis of urea nitrogen concentration.

Spot fecal samples were collected directly from the animals' rectums on the 15th to 20th days of each experimental period, at different times after feeding ( $6 \mathrm{~h} 00 \mathrm{~min} ; 8 \mathrm{~h} 00 \mathrm{~min} ; 10 \mathrm{~h} 00$ $\mathrm{min} ; 12 \mathrm{~h} 00 \mathrm{~min}$ and $14 \mathrm{~h} 00 \mathrm{~min}$ ). Spot urine samples were obtained on the 15th day of each experimental period, $4 \mathrm{~h}$ after the first feed supply of the day [13]. The urine was filtered through gauze, and a $10-\mathrm{mL}$ aliquot was diluted immediately in $40 \mathrm{~mL} 0.036 \mathrm{~N}$ sulfuric acid and stored at $-20^{\circ} \mathrm{C}$ for later analyses of urea, allantoin [14], and uric acid [15]. Creatinine was evaluated using a colorimetric system with commercial kits (Labtest Diagnóstica S.A. Lagoa Santa, MG, Brazil).

The daily urinary excretion of creatinine was estimated from the proposed creatinine excretion of $24.05 \mathrm{mg} / \mathrm{kg}$ of live weight [13]. Microbial protein synthesis was calculated as described by [13], considering a recovery of absorbed purines of 0.85 and an endogenous contribution to the excretion of purines as recommended by [16].

To estimate the apparent digestibility coefficients, the indigestible neutral detergent fiber (iNDF) was used as an internal marker, obtained after $288 \mathrm{~h}$ of ruminal incubation time [17]. Samples of the feeds, orts, and feces were analyzed to determine the concentrations of DM, mineral matter, and CP according to [18]. The concentration of NDF was assayed with a heatstable amylase and corrected for ash based on the procedures described by [19]. Neutral detergent insoluble nitrogen was estimated according to [20]. Non-fiber carbohydrates were calculated according to [21] and the intake of total digestible nutrients (TDN) was calculated according to [22].

The variables were analyzed with PROC MIXED in SAS software (version 9.4), for variance and regression analysis, according the statistic model: 


$$
\mathrm{y}_{\mathrm{ijkl}}=\mu+\tau_{\mathrm{i}}+\mathrm{Q}_{\mathrm{j}}+\mathrm{P}_{\mathrm{k}}+(\mathrm{A} / \mathrm{Q})_{\mathrm{lj}}+\tau \times \mathrm{Q}_{\mathrm{ij}}+\varepsilon_{\mathrm{ijk \textrm {k }}}
$$

Where, $\mathrm{y}_{\mathrm{ijk} \mathrm{l}}=$ observation $\mathrm{ijkl} ; \mu=$ general mean; $\tau_{\mathrm{i}}=$ treatment fixed effect $i ; Q_{j}=$ square fixed effect $j ; P_{k}=$ period fixed effect $\mathrm{k} ;(\mathrm{A} / \mathrm{Q})_{\mathrm{lj}}=$ animal $\mathrm{l}$ into square $\mathrm{j}$ random effect; $\tau \times \mathrm{Q}_{\mathrm{ij}}$ $=$ interaction effect of treatment $\mathrm{i}$ and square $\mathrm{j} ; \boldsymbol{\varepsilon}_{\mathrm{ijkl}}=$ random error with mean 0 and variance $\sigma^{2}$.

Dunnett test was used to compare each treatment group mean (sugarcane bagasse levels), with an average of the control diet (based on spineless cactus and sugarcane bagasse). Comparisons between sugarcane bagasse levels in the diets were conducted by the sum decomposition of squares in orthogonal contrasts to linear, and quadratic effects $(\mathrm{p}<0.05)$, with subsequent adjustments of regression equations.

\section{RESULTS}

The nutrient intake and apparent digestibility of cows fed control diet or different levels of sugarcane bagasse are presented in Table 3 below. The DM, organic matter (OM) and TDN intakes and DM and OM digestibilities of cows fed $45 \%$ and $50 \%$ sugarcane bagasse were similar to control diet ( $\mathrm{p}>0.05)$ while for cows fed $55 \%$ and $60 \%$ levels of bagasse were lowest $(\mathrm{p}<0.05)$. The intake and digestibility of CP diets with $45 \%$, $50 \%$, and $55 \%$ of sugarcane bagasse were the same related to control diet ( $p>0.05)$. The non-fiber carbohydrate intake and digestibility for cows fed $45 \%$ of bagasse were similar for control diet ( $p>0.05)$. The neutral detergent fiber assayed with a heat stable amylase and corrected for ash and nitrogenous com- pounds (aNDF[n]) and NDF indigestible intakes and $\mathrm{aNDF}(\mathrm{n})$ digestibility differ for all sugarcane bagasse inclusion related to control diet ( $p>0.05)$. A linear decrease was observed to intakes and digestibilities of nutrients with the bagasse levels $(\mathrm{p}<0.05)$, except for $\mathrm{aNDF}(\mathrm{n})$ and NDF intakes and $\mathrm{aNDF}(\mathrm{n})$ digestibility.

The feeding time was the same for control diets and all bagasse level diets ( $p>0.05$; Table 4$)$. The ruminating and idle time for cows fed $45 \%, 50 \%$, and $55 \%$ of sugarcane bagasse was the same as that related to the control diet. For $60 \%$ of bagasse inclusion, the ruminating time was lower and the idle time was greater than the control diet $(\mathrm{p}<0.05)$. It was observed same results on feeding efficiency for $45 \%, 50 \%$, and $55 \%$ bagasse levels and control diet. Ruminating efficiency was the same between $45 \%$ and $50 \%$ of bagasse inclusion and control diet. Ruminating time and efficiency of feeding and rumination decreased, while the idle time increased linearly with sugarcane bagasse inclusion in diets $(\mathrm{p}<0.05)$.

The daily milk production for cows fed $45 \%$, and $50 \%$ was similar as that of cows fed control diet ( $p>0.05$; Table 5), while for those fed $55 \%$, and $60 \%$ levels of sugarcane bagasse, the production was lower. The fat, protein, lactose, and total solids of milk were the same for bagasse levels and the control diet ( $p>0.05)$. The urea in the milk and plasma were greater for cows fed sugarcane bagasse diets related to control diet $(\mathrm{p}<$ 0.05). The allantoin concentration in milk and microbial protein synthesis for $45 \%$ and $50 \%$ of bagasse levels were similar to control diet. A linear decrease was observed for daily milk production, fat-corrected milk production, allantoin, and mi-

Table 3. Nutrient intake and apparent digestibility in cows fed sugarcane bagasse

\begin{tabular}{|c|c|c|c|c|c|c|c|c|}
\hline \multirow{2}{*}{ Item } & \multirow{2}{*}{ Control } & \multicolumn{4}{|c|}{ Sugarcane bagasse (\%) } & \multirow{2}{*}{ SEM } & \multicolumn{2}{|c|}{$p$ value } \\
\hline & & 45 & 50 & 55 & 60 & & $\mathbf{L}$ & Q \\
\hline \multicolumn{9}{|l|}{ Daily intake (kg/d) } \\
\hline Organic matter & 13.9 & 13.9 & 13.4 & $12.3^{*}$ & $10.8^{*}$ & 0.314 & $<0.001$ & 0.176 \\
\hline Crude protein & 2.11 & 2.24 & 2.14 & 2.00 & $1.78^{*}$ & 0.043 & $<0.001$ & 0.239 \\
\hline aNDF(n) & 3.17 & $5.17^{\star}$ & $5.30^{*}$ & $5.22^{*}$ & $4.98^{*}$ & 0.182 & 0.430 & 0.320 \\
\hline NFC & 7.47 & 5.91 & $5.25^{*}$ & $4.48^{*}$ & $3.58^{*}$ & 0.078 & $<0.001$ & 0.136 \\
\hline TDN & 8.84 & 9.40 & 8.38 & $7.18^{*}$ & $5.91^{*}$ & 1.318 & $<0.001$ & 0.153 \\
\hline \multicolumn{9}{|c|}{ Daily intake (g/kg of BW) } \\
\hline Dry matter & 3.36 & 3.25 & 3.11 & $2.86^{*}$ & $2.51^{*}$ & 0.074 & $<0.001$ & 0.186 \\
\hline aNDF(n) & 1.02 & $1.29 *$ & $1.32^{*}$ & $1.29 *$ & $1.21^{*}$ & 0.045 & 0.227 & 0.242 \\
\hline \multicolumn{9}{|c|}{ Total apparent digestibility (g/kg) } \\
\hline aNDF(n) & 310 & $581^{*}$ & $528^{*}$ & $494^{*}$ & $428^{*}$ & 2.81 & 0.003 & 0.640 \\
\hline NFC & 772 & 700 & $662^{*}$ & $574^{*}$ & $487^{*}$ & 2.70 & 0.001 & 0.941 \\
\hline
\end{tabular}

SEM, standard error of the mean; L, linear effect; Q, quadratic effect; BW, body weight; aNDF(n), neutral detergent fiber assayed with a heat stable amylase and corrected for ash and nitrogenous compounds; iNDF, indigestible neutral detergent fiber; NFC, non-fiber carbohydrates; TDN, total digestible nutrients.

*Values differ statistically from the control treatment by Dunnett test at the level of $5 \%$ probability $(p<0.05)$. 
Table 4. Ingestive behavior of cows fed sugarcane bagasse

\begin{tabular}{|c|c|c|c|c|c|c|c|c|}
\hline \multirow{2}{*}{ Item } & \multirow{2}{*}{ Control } & \multicolumn{4}{|c|}{ Sugarcane bagasse (\%) } & \multirow{2}{*}{ SEM } & \multicolumn{2}{|c|}{$p$ value } \\
\hline & & 45 & 50 & 55 & 60 & & L & Q \\
\hline \multicolumn{9}{|c|}{ Time (minutes/d) } \\
\hline Feeding & 322 & 306 & 287 & 294 & 307 & 0.183 & 0.844 & 0.162 \\
\hline Ruminating & 621 & 667 & 652 & 605 & $541^{*}$ & 0.099 & $<0.001$ & 0.048 \\
\hline Idle & 497 & 467 & 501 & 541 & $592^{*}$ & 0.180 & $<0.001$ & 0.332 \\
\hline \multicolumn{9}{|c|}{ Efficiency (kg DM/h) } \\
\hline Feeding & 2.84 & 2.88 & 2.95 & 2.68 & $2.24^{*}$ & 0.144 & 0.003 & 0.095 \\
\hline Ruminating & 1.88 & 1.90 & 1.70 & $1.45^{*}$ & $1.17^{*}$ & 0.379 & $<0.001$ & 0.332 \\
\hline
\end{tabular}

SEM, standard error of the mean; L, linear effect; $Q$, quadratic effect; DM, dry matter.

* Values differ statistically from the control treatment by Dunnett test at the level of $5 \%$ probability $(p<0.05)$.

crobial protein synthesis $(\mathrm{p}<0.05)$ with sugarcane bagasse diets increase. Neither the milk and plasma urea or microbial protein efficiency were altered by bagasse inclusion, while microbial $\mathrm{CP}$ synthesis decreased linearly with sugarcane bagasse increase in diets.

\section{DISCUSSION}

The greater nutritional value observed in for control diet is related to inclusion of spineless cactus, and it was reflected in the milk production, as expected and observed by [23]. The spineless cactus witnessed greater acceptability by animals and highest digestibility of nutrients. The diet composition of control promotes adequate a balance between supplied energy and protein [24], resulting in improved efficiency of the nitrogenous compound usage. This is reaffirmed by the data presented in Table 5; milk urea was lower for cows fed control diet than all other diets based on bagasse, and this value being lower than the maximum value recommended (21.71 $\mathrm{mg} / \mathrm{dL}$ of milk) [25].

The levels of sugarcane bagasse of $45 \%$ and $50 \%$ present same DM, OM, TDN intake, and milk production than control diet due to high concentrated feedstuffs inclusion in those diets, which was reflected in feed efficiency (Table 5). The control diet was superior to diets containing sugarcane bagasse due to lower concentrated inclusion in its composition.

Although it is not an immediate solution, and considering the consequences of severe droughts and plague (Dactylopius opuntias), the presented results denote the importance of resistant pest spineless cactus genotypes for dairy cattle farmers in arid and semi-arid regions, once the concentrated ingredients have demanded high prices in recent years.

The lower DM and nutrient intake was related to higher

Table 5. Performance, milk composition, blood and milk urea nitrogen and microbial protein synthesis of cows fed sugarcane bagasse

\begin{tabular}{|c|c|c|c|c|c|c|c|c|}
\hline \multirow{2}{*}{ Item } & \multirow{2}{*}{ Control } & \multicolumn{4}{|c|}{ Sugarcane bagasse (\%) } & \multirow{2}{*}{ SEM } & \multicolumn{2}{|c|}{$p$ value } \\
\hline & & 45 & 50 & 55 & 60 & & L & Q \\
\hline \multicolumn{9}{|l|}{ Performance } \\
\hline $\mathrm{FCM}(\mathrm{kg} / \mathrm{d})$ & 12.8 & 12.8 & 12.2 & 11.4 & $9.51^{*}$ & 0.294 & $<0.001$ & 0.256 \\
\hline Feed efficiency (kg FCM/kg DM intake) & 0.85 & 0.87 & 0.87 & 0.88 & 0.84 & 0.456 & 0.685 & 0.178 \\
\hline \multicolumn{9}{|l|}{ Milk composition } \\
\hline Protein (g/100 g) & 3.84 & 3.67 & 3.72 & 3.75 & 3.74 & 0.069 & 0.687 & 0.820 \\
\hline Lactose $(\mathrm{g} / 100 \mathrm{~g})$ & 4.43 & 4.50 & 4.49 & 4.48 & 4.43 & 0.015 & 0.149 & 0.587 \\
\hline Total solids (g/100 g) & 13.7 & 13.5 & 13.9 & 14.0 & 13.5 & 0.150 & 0.861 & 0.154 \\
\hline Allantoin (mmol/d) & 43.8 & 42.6 & 41.3 & $34.7^{*}$ & $30.1^{*}$ & 1.450 & $<0.001$ & 0.225 \\
\hline \multicolumn{9}{|l|}{ Urea nitrogen (mg/dL) } \\
\hline Milk & 12.2 & $19.6^{*}$ & $20.6^{*}$ & $24.2^{*}$ & $22.4^{*}$ & 0.873 & 0.137 & 0.429 \\
\hline micEF (g CP/kg of TDN) & 128 & 119 & 122 & 119 & 138 & 5.875 & 0.134 & 0.278 \\
\hline
\end{tabular}

SEM, standard error of the mean; L, linear effect; Q, quadratic effect; FCM, fat-corrected milk; DM, dry matter; micCP, microbial crude protein; micEF, efficiency of microbial protein synthesis; TDN, total digestible nutrients.

* Values differ statistically from the control treatment by Dunnett test at the level of $5 \%$ probability $(p<0.05)$. 
indigestible fiber (iNDF) content in diets with increasing levels of sugarcane bagasse (55\% and 60\%), causing distension in the rumen and consequent ruminal filling [26]. This result was confirmed by the ingestive behavior, which showed decrease in the rumination time and efficiency (Table 4). The excess of low degradability fiber promoted the decrease in DM and NDF digestibility in function of bagasse levels inclusion; consequently, the animals ingested the feed until they reached their maximum capacity for NDF intake, reflecting in other nutrients intake (Table 3). According to [27], sugarcane bagasse has low NDF digestibility and high lignin content, which reduces the passage rate of digestion from the gastrointestinal tract, and results in an increased retention time. As the feeding time, did not vary and the DM intake reduced with bagasse inclusion, it reflected in feeding efficiency $(\mathrm{kg} \mathrm{DM} / \mathrm{h})$ that decreased with bagasse increases. This response is related to diet composition; the high level of bagasse presented long particles which caused difficulty in apprehension and low acceptability.

The lower milk production observed for cows fed $55 \%$ and $60 \%$ of bagasse inclusion is explained by their lower intake of DM and TND, which was lower than the energy requirements for that category and milk production level. For the bagasse levels of $45 \%$ and $50 \%$, it was observed the expected milk production according to diet control, confirming that the nutritional requirements were attended $(14 \mathrm{~kg} / \mathrm{d}$ of DM and $7.6 \mathrm{~kg} / \mathrm{d}$ of TDN; Table 3). In addition to the greater TDN intake, the greater microbial protein synthesis was an important source of milk production precursor too, as it presents a high-quality amino acid profile and most amino acids absorbed in the small intestine come from microbial protein [28].

The energy intake also is related to microbial protein synthesis, once the availability of nitrogen and energy in the rumen are listed as main factor to limit microbial growth [29]. The microbial protein synthesis decreased linearly with bagasse increase, presenting a maximum microbial production of $1,127 \mathrm{~g} / \mathrm{d}$ for $45 \%$ bagasse inclusion, diet that promoted greater TDN intake $(9.40 \mathrm{~kg} / \mathrm{d}$; Table 3$)$ when compared with greater inclusion sugarcane bagasse diets. For all levels inclusion of bagasse, microbial protein synthesis efficiency (124.5 g CPmic/ $\mathrm{kg}$ TDN) is in accordance with the values recommended for animals raised under tropical conditions, of $120 \mathrm{~g}$ microbial $\mathrm{CP} / \mathrm{kg}$ TDN [30].

Diets based on sugarcane bagasse requires high concentrated levels when compared to diet control (Table 2), which reaffirms the bagasse's low nutritional value and justifies the importance of maintaining the spineless cactus cultivation in semiarid. Nevertheless, the spineless cactus areas recovery is a slowly process, which highlights the importance of sugarcane bagasse co-product for dairy cattle diets as demonstrated in the presented discussion.

Therefore, the sugarcane bagasse is valuable alternative and it is recommended the inclusion of $45 \%$ and $50 \%$ associated to concentrated feedstuffs for replacing diets based on spineless cactus for crossbred dairy cow's producing $12 \mathrm{~kg} / \mathrm{d}$ of milk. The bagasse levels of $55 \%$ and $60 \%$ should be utilized for cow with lower milk production.

\section{IMPLICATIONS}

The paper provides brand new animal production and nutrition information, relating to sugarcane bagasse, agro-industrial waste, for lactating cow's diets. Although sugarcane bagasse is extremely used in beef cattle feedlot diets, there is no given for lactating dairy cattle. The bagasse has been a valuable alternative, and medium-term, and it is unique viable roughage for ruminants in Brazilian semiarid since the roughage used in this areas, the spineless cactus, disappeared due to insectplague associated with several droughts that occurred last year. The spineless cactus fields reestablishment with resistant pest genotypes is an option for the medium and long-term.

\section{CONFLICT OF INTEREST}

We certify that there is no conflict of interest with any financial organization regarding the material discussed in the manuscript.

\section{ACKNOWLEDGMENTS}

The authors are grateful to the Brazilian foundation, Conselho Nacional de Desenvolvimento Científico e Tecnológico (CNPq) by financial support, and Fazenda Roçadinho by the availability of trial conduction.

\section{REFERENCES}

1. MDA - Ministério da Agricultura Familiar e do Desenvolvimento Agrário [Internet]. UN reforces smallholder livestock system importance to the world; 2014 [cited 2017 Mar 15]. Available from: http://www4.planalto.gov.br/consea/comunicacao/ noticias/2014/onu-reforca-a-importancia-da-agriculturafamiliar-para-o-mundo

2. Ben Salem H. Nutritional management to improve sheep and goat performances in semiarid regions. R Bras Zootec 2010;39: 337-47 (supl. especial).

3. FAO (Food and Agriculture Organization) [Internet]. Drylands, people and land use; 2008 [cited 2017 Mar 14]. Available from: http//http://www.fao.org/docrep/012/i0372e/i0372e01.pdf

4. Ferreira MA, Silva RR, Ramos AO, et al. Microbial protein synthesis and urea concentration for cows fed diets based on spineless cactus and different forages. R Bras Zootec 2009;38: 159-65.

5. Hofsetz K, Silva MA. Brazilian sugarcane bagasse: Energy and non-energy consumption. Biomass Bioenergy 2012;46:564- 
73.

6. Costa DA, Souza CL, Saliba EO, Carneiro JC. By-products of sugar cane industry in ruminant nutrition. Int J Adv Agric Res 2015;3:1-9.

7. Barros RC, Rocha Júnior VR, Souza AS, et al. Economic viability of substitution of sorghum silage by sugarcane or sugarcane bagasse ammoniated with urea for cattle in feedlot. Rev Bras Saude Prod Anim 2010;11:555-69.

8. Leme PR, Silva SI, Pereira ASC, et al. Sugarcane bagasse utilization in diets with high-proportion of concentrated for Nelore cattle in the feedlot. R Bras Zootec 2003;32:1786-91.

9. Köppen W. Climatology: Earth climate studies. México City, Mexico: Fondo de Cultura Economica; 1948. 478 p.

10. National Research Council. Nutrient requirements of dairy cattle. 7th ed revised. Washington, DC, USA: National Academic Science; 2001.

11. Martin P, Bateson P. Measuring behavior: an introductory guide. 3th ed. 380: Cambridge UK: Cambridge University Press; 2007. $176 \mathrm{p}$.

12.ISO 9622/IDF 141C. Determination of milk fat, protein, lactose, and urea content: Guidance on the operation of mid-infrared instruments. Bruxelas, Belgium: 2013. 14 p.

13. Chizzotti ML, Valadares Filho SC, Valadares RFD. Determination of creatinine excretion and evaluation of spot urine sampling in Holstein cattle. Livest Sci 2008;113:218-25.

14. Chen XB, Gomes MJ. Estimation of microbial protein supply to sheep and cattle based on urinary excretion of purine derivatives - an overview of technical details. Aberdeen, UK: International Feed Research Unit. Rowett Research Institute; 1992 (occasional publication). $21 \mathrm{p}$.

15.George SK, Dipu MT, Mehra UR, et al. Improved HPLC method for the simultaneous determination of allantoin, uric acid and creatinine in cattle urine. J Chromatogr B 2006;832: 134-7.

16. González-Ronquillo M, Balcells J, Guada JA. Purine derivative excretion in dairy cows: Endogenous excretion and the effect of exogenous nucleic acid supply. J Dairy Sci 2003;86:1282-91.

17. Valente TNP, Detmann E, Sampaio CB. Review: recent advances in evaluation of bags made from different textiles used in situ ruminal degradation. Can J Anim Sci 2015;95:493-8.
18. AOAC - Official Methods of Analysis, 15th ed. Association of Official Analytical Chemists, Arlington VA, USA: AOAC International; 1990.

19. Mertens DR. Gravimetric determination of amylase-treated neutral detergent fiber in feeds with refluxing in beakers or crucibles: collaborative study. J AOAC 2002;85:1217-40.

20.Licitra G, Hernandez TM, Van Soest PJ. Standardization of procedures for nitrogen fractionation of ruminant feeds. Anim Feed SciTechnol 1996;57:347-58.

21. Hall MB. Challenges with non-fiber carbohydrate methods. J Anim Sci 2003;81:3226-32.

22.Sniffen CJ, O'connor JD, Van Soest PJ, Fox DG, Russel JB. A net carbohydrate and protein system for evaluating cattle diets; II. Carbohydrate and protein availability. J Anim Sci 1992;70:3562-77.

23. Ferreira MA, Pessoa RAS, Bispo SV. Optimize of diets based on spineless cactus and other supplementation alternatives in the semiarid region. In: VI Beef Cattle Production Simposium; 2007. Viçosa Brazil: UFV; 2007. p. 241-66.

24.Pereira ES, Arruda AMV, Miranda LF, et al. Carbohydrates and protein inter-relationship importance in ruminants diets. Semen: Cien Agrar 2005;26:125-34.

25. Torrent J. Milk urea nitrogen and milk qualitty. In: Milk Quality International Simposium, 2. 2000. Curitiba, Brazil: Anais Curitiba: CIETEP/FIEP, 27-9.

26. Van Soest PJ. Nutritional ecology of the ruminant. 2th ed. Ithaca, NY, USA: Cornell University Press; 1994.476 p.

27. Oliveira MDS, Casagrande AA, Oliveira EFS. Effect of in vitro digestibility of sugarcane varieties according to its value as the feed component for cattle. Ars Vet 2001;17:238-43.

28. Titgemeyer EC. Amino acid utilization by growing and finishing ruminants. In: D'Mello JPF, editors. Amino acids in animal nutrition. Wallingford, UK: CAB International; 2003. p. 329-46.

29. Clark JH, Klusmeyer TH, Cameron MR. Microbial protein synthesis and flowers of nitrogen fractions to the duodenum of dairy cows. J Dairy Sci 1992;27:2304-23.

30. Valadares Filho SC, Paulino PVR, Magalhães KA, et al. Nutritional requirements of Zebu cattle and feed composition tables - BR Corte. 1th ed. Viçosa, MG, Brazil: Suprema; 2006. 142 p. 